\title{
NON-SPECIFIC MORPHOLOGICAL CHANGES IN THE ORGANS OF CHICKENS INFECTED EXPERIMENTALLY WITH MAREK'S DISEASE VIRUSES
}

\author{
R. HALOUZKA ${ }^{1}$ and V. JURAJDA ${ }^{2}$ \\ Department of Pathomorphology, ${ }^{1}$ Clinic of Avian Diseases, ${ }^{2}$ University of Veterinary Science, \\ 61242 Brno
}

Received September 25, 1991

\begin{abstract}
Halouzka, R., V. Jurajda: Non-Specific Morphological Changes in the Organs of Chickens Infected Experimentally with Marek's Disease Viruses. Acta vet. Brno, 61, 1992: 123-131.

Description is given of hitherto unnoticed pathological changes in the organs of Hybro, White Hisex, $F_{1}$ inbred line $C B \times I A$ and Brown Leghorn chickens after experimental infection with oncogenic strains (GA, field isolates VUB-83 and $\mathrm{RB}-1 \mathrm{~B}$ ) and non-oncogenic strains (field isolates $M$ and $\mathrm{K}$ ) of Marek's disease virus (MDV). The chickens were infected on the 2 nd post-hatching day and sacrificed at weekly intervals up to the 5 th week p. i. Pathomorphological examination revealed, in addition to $M D$-specific and cytolytic morphological changes in the organs, the presence of syncytial formations, granulomas, "Hassall's corpuscle-like" structures, dystrophic changes in follicular epithelium-associated (FAE) cells and changes in the corticomedullary membrane of the bursa of Fabricius follicles, hypertrophy and hyperplasia of Hassall's corpuscles, hyperplasia of myoid elements in the thymus, spheroids in peripheral nerves and glomerulopathy.

The changes observed in the lymphoid organs are regarded as a morphological manifestation of local cellular defence, and the changes in the nerves and kidney as an autoimmune process and, consequently, as non-specific of MD. Their description contributes to a better understanding of the complex pathogenesis of Marek's disease of poultry.

Marek's disease, non-specific morphological changes, lymphoid organs, cellular immunity
\end{abstract}

A characteristic feature of Marek's disease of poultry (MD) as of many other herpes virus-produced diseases is a differing type of virus-cell interaction, ranging from fully productive and semi-productive infection to non-productive neoplastic and non-productive latent infection (Payne 1985). However, the final outcome of infection with Marek's disease virus (MVD) is strongly affected by pathogenicity of the viral strain, genotype of the host and its immune status. The main pathological changes occurring in the organs during the complex pathogenesis of MD produced by different MDV strains are well-known (Calnek 1986).

Lymphoid infiltration and proliferation, and development of lymphomas are regarded as specific of MD (Payne and Biggs 1967). That MDV is lymphotropic appears also from cytolytic changes with a secondary inflammatory reaction in lymphoid organs, particularly in the bursa of Fabricius (BF), which we do not regard as specific of MD but as a major criterion of the pathogenicity of MVD (Halouzka and Juraida 1991).

The cell structure of the BF corresponds in essence to the germinal centres of mammalian lymphoreticular tissues and performs the function of a peripheral lymphoid organ (Toivanen et al. 1987). It can therefore be assumed that the morphological changes arising in lymphoid follicles of the bursa after antigenic stimulation are also a manifestation of local immune response.

Our experimental studies of the pathogenesis of $M D$ revealed, in addition to specific changes in various tissues and regressive changes in the lymphoid organs of poultry, also some other changes that have not been generally described in the pathogenesis of MD. The object of the present study is to describe these unusal changes designated by us as non-specific of MD and point out their formal and causal pathogenesis. 


\section{Materials and Methods}

There oncogenic MDV strains were used. Prototype strain Georgia (GA) (Eids on and Sch mittle 1968) was administered in doses of approximately $1.6 \cdot 10^{3}$ and $1.6 .10^{4}$ PFU to 1-old meat-type Hybro chicks, layer-type White Hisex chicks and to $F_{1}$ inbred line $C B \times I A$ chicks that are more resistant to MD than Brown Leghorns (BrL) (Jurajda et al. 1989). A highly oncogenic MDV strain VUB-83 (Jurajda and Halouzka 1989) was administered to 1-day old Hybro, White Hisex and BrL chicks in the same doses as MDV strain GA. An oncogenic MDV strain RB-1B (Jurajda and Halouzka 1990) was administered to BrL chicks in doses of approximately $10^{2}, 10^{3}$ and $10^{4} \mathrm{PFU}$ in $0.2 \mathrm{ml}$ inoculum volumes.

The non-oncogenic MDV strains used in our study were field isolates $M$ and $\mathrm{K}$ (Jurajda and Halouzka 1991). They were administered to 2-day old BrL chicks in doses of approximately $10^{2}, 10^{3}$ and $10^{4}$ PFU in $0.2 \mathrm{ml}$ inoculum volumes (Halouzka and Jurajda 1991).

Ten chickens of each infected group were sacrificed, together with 10 controls, 1, 2, 3 and 5 weeks p. i. All of them were subjected to pathomorphological examination. Samples for histopathological examination were taken from lymphoid organs, skin, peripheral nerves, gonads, liver and kidney. They were fixed in $10 \%$ aqueous solution of neutral formaldehyde and stained with haematoxylin and eosin, Giemsa stain and luxol blue. Cytolytic changes in the lymphoid organs were assessed quantitatively using immunosuppression ( $\mathrm{Si}$ ) degrees of 0 to 4 (Halouzka and Jurajda 1991).

\section{Results}

Unusual morphological changes were observed in the BF, thymus, skin, peripheral nerves and kidney of experimental chickens. The frequency of these changes varied from experiment to experiment and in dependence on the post-infection period.

\section{Bursa of Fabricius}

In the germinal centres of lymphoid follicles classified as $\mathrm{Si}$ degrees 2 to 3, syncytial formations ( 1 to 3 in number), arisen by fusion of 2 to 5 dentritic reticular cells, were observed (Fig. 1). Some of them corresponded to the morphological characteristics of large polykaryons, others were reminiscent Hassall's corpuscles of the thymus. They were found most frequently in Hybro chickens, $\mathrm{CB} \times$ IA hybrids and White Hisex chickens 1 and 2 weeks after infection with strain GA and in BrL chickens 3 weeks after infection with strain $M$ and considerably less frequently 1 week after infection with strain $\mathrm{K}$. In the experiments with strain VUB-83 they were observed only sporadically 1 week p. i. in Hybro and White Hisex chickens. In all experiments they were found very rarely also in non-infected controls (in a total of 5 control birds).

In experiments with strain $\mathrm{K}$ some syncytial formations gave rise to structures morphologically identical with minute granulomas showing central markedly eosinophilic necrosis rimmed with cells with signs of epitheloid elements.

Vacuolar and dystrophic changes to necrosis of follicular epithelium-associated (FAE) cells constituting the surface epithelium of the villi were an accompanying phenomenon of cytolytic changes in the follicular medulla from the 3rd week p. i. in all experiments (Fig. 2). Sporadically, their protrusion to desquamation to the cavity of the organ was observed.

Distorsion and thickening of the corticomedullary membrane of the follicles and transition of flat epithelial cells to cubic ones was seen in all cases classified as Si degree 2 to 4 , particularly where marked lymphocyte depletion of the follical medulla was observed. These changes were conspicuous mainly in BrL chickens infected with MDV strains VUB-83, ,GA and K. 


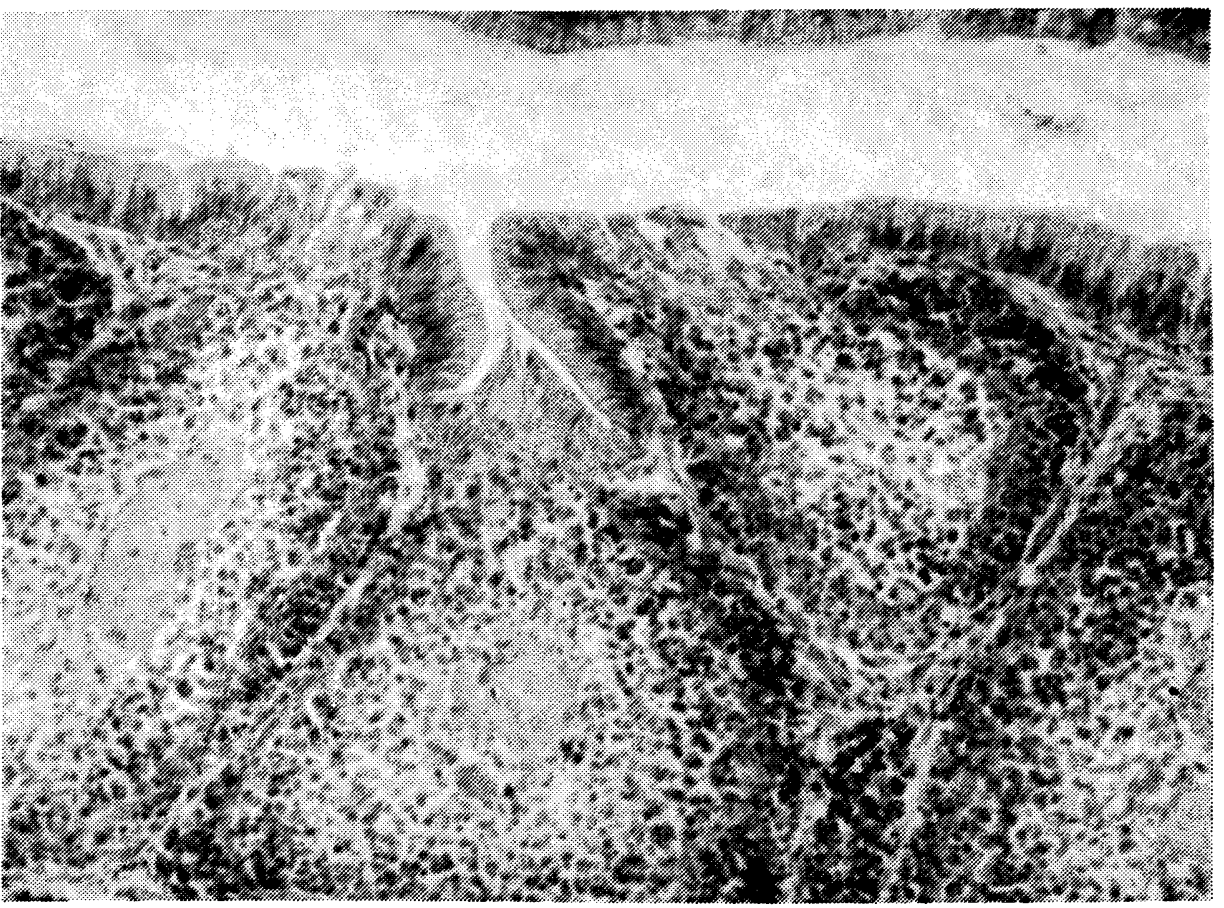

Fig. 1. Production of syncytial structures in the germinal centres of lymphoid follicles in the bursa of Fabricius. HE $\times 640$.

\section{'Thymus}

Hyperplasia and hypertrophy of Hassall's corpuscles due to increased hyalinization of epithelial cells, frequently in the form of concentric hyaline layers, accompanied the regressive changes in the thymus (Fig. 3). With the higher Si degrees this phenomenon was more pronounced and the centres of Hassall's corpuscles showed cavities containing chromatin granules and residues of cellular bodies. These corpuscles were rimmed with granulocytes. The incidence of altered Hassall's corpuscles was associated with an increase of myoid elements and with the development of germinal lymphoid centres in the medulla. Although these changes were observed in all experiments, they were most frequent 1 week after infection with strains GA and VUB-83 in Hybro and White Hisex chickens and 2 and 3 weeks after infection with strains $M$ and $\mathrm{K}$ in $\mathrm{BrL}$ chickens.

\section{Skin}

In $\mathrm{BrL}$ chickens infected with strain $\mathrm{K}$ feather-pulp changes were regular findings in addition to well-known skin lesions. A conspicuous finding was an enlarged capillary network and mixed cellulization of the thin mesenchymal reticulum of the medulla round the veins. The medulla itself was markedly eosinophilic and showed dissociation of the structure. These changes affected more chickens and at a higher intensity at the end of the experiment, being particularly intense in the group given the high virus dose. 
Peripheral Nerves

Multiple spheroid eosinophilic to amphophilic formations in neuraxons (Fig. 4) accompanied by granulation of myelin sheaths of the surrounding neurits were frequent and marked findings in RB-1B-infected BrL chickens from the 3 rd post-infection week. These lesions were accompanied neither by interneuritic nor perineural lymphoid infiltration nor by any damage to Schwann cells.

\section{Kidney}

Two BrL chickens infected with strain GA showed proliferation of mesangial cells, thickening of the basement membranes and swelling of the endothelia of capillaries in some glomeruli 5 weeks p. i. (Fig. 5). These changes were accompanied by MD-specific pleiomorphic infiltration of the intertubular tissue.

\section{Discussion}

Syncytial formations, also referred to as polykaryons or "Hassall's corpuscle-like" structures, in the medulla of lymphoid follicles of the BF have not been described in the literature on the pathogenesis of $M D$ before. However, avian germinal centres of the BF follicles are known to contain, besides T- and B-lymphocytes, also macrophages and dentritic reticular cells (Jeurissen et al. 1989).

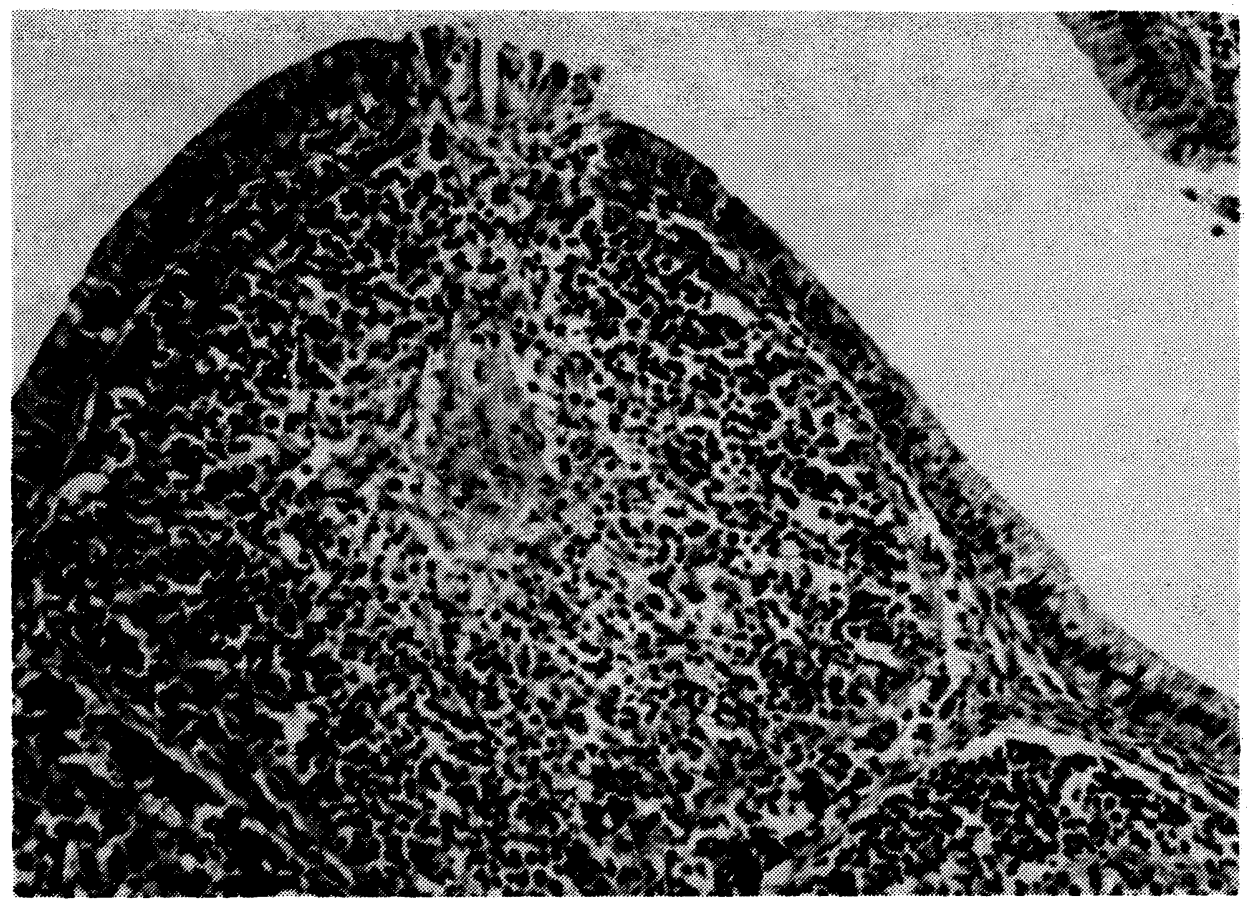

Fig. 2. Dystrophic changes of FAE cells in the surface epithelium of the villi in the bursa of Fabricius. He $\times 640$. 


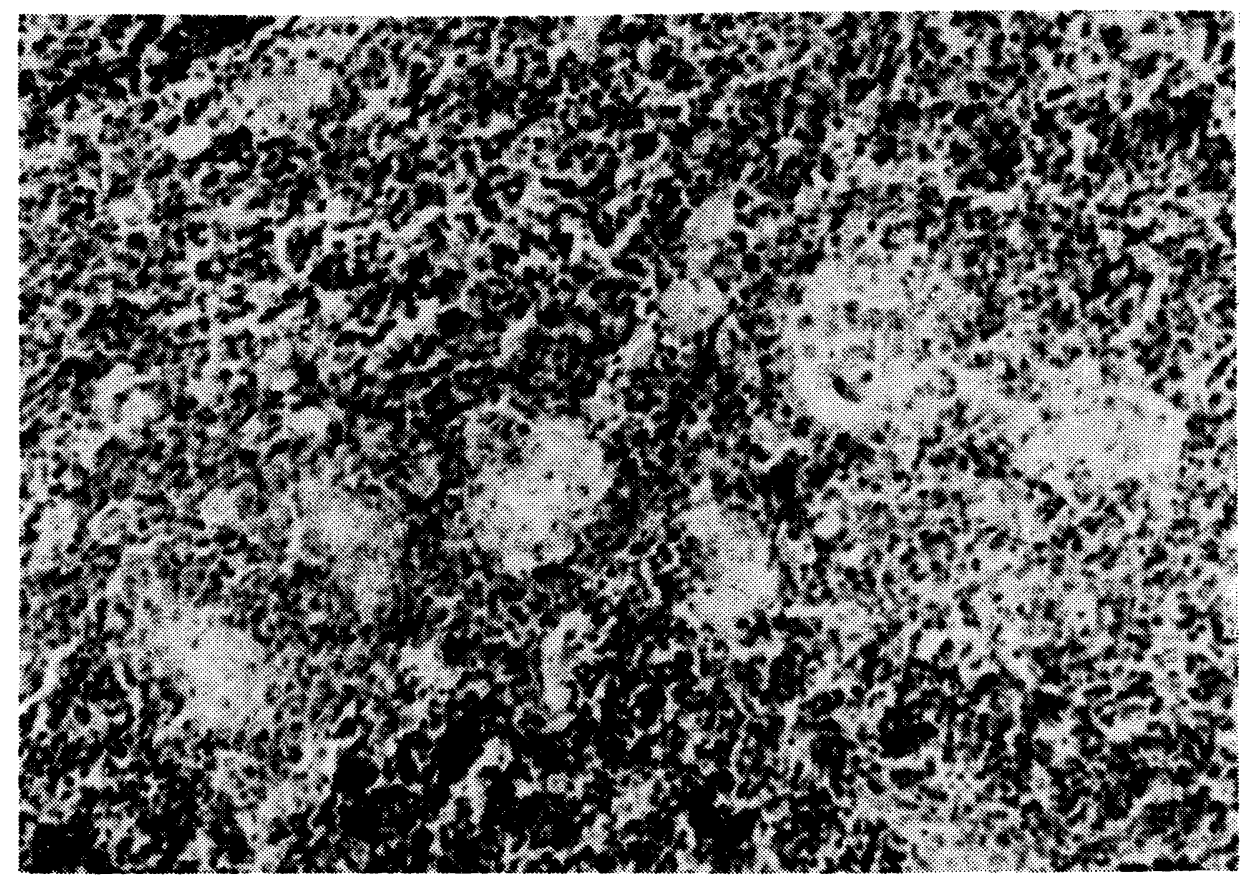

Fig. 3. Hypertrophy and hyperplasia of Hassall's corpuscles in the thymus. $\mathrm{He} \times 640$.

Moreover, the avian follicular medulla contains another two cell types that have not been identified in mammals, namely follicular epithelial cells between the medullary and cortical parts of the follicles and "Hassall's corpuscle-like" structures consisting of epithelial cells (Naukkarinen and Sorvari 1982). Structures in the germinal centres of mammalian lymphoreticular tissues identical with the syncytial structures found by us in the follicular medulla of the BF have been described at these locations after antigenic stimulation. Macrophages are transformed to cells epitheloid in appearance and fused (Syrjanen 1982). In our view, the syncytia, or polykaryons, in the BF follicular medulla are therefore a morphological manifestation of cellular immunity after antigenic stimulation with MDV virus as is the increase in, and enlargement of, "Hassall's corpuscle-like" structures.

In the light of our observations the formation of granulomas in the BF can be regarded as an enhanced immune response to stimulation with MDV. From the viewpoint of general pathology epitheloid granulomas represent T-cell-mediated type of immunity and are a favourable reaction of the body (Bednár 1982). To a certain extent, they can be therefore regarded as morphological manifestation of the relation between the pathogenicity of MDV strain $\mathrm{K}$ and the defence potential of $\mathrm{BrL}$ chickens. In other experiments the granulomatous type of reaction was not observed.

FAE cells are of mesenchymal origin and have, similarly to mammalian $M$-cells. (Lupetti et al. 1983a, b; Toivanen et al. 1987), an important function in antigen transport. Dystrophic changes of FAE cells after infection with MDV 
are apparently a result of the interaction between the virus and these cells, similarly to cytolytic changes in other elements of mesenchymal origin.

The incidence of pathologically altered Hassall's corpuscles of the thymus correlated with the production of granulomas in the BF. Avian thymus has also the properties of a peripheral lymphoid organ, and reticular epithelium has the ability of phagocytosis (Jankovič et al. 1972 as cited by Benda 1990). Cytolytic infection results in the proliferation of reticular epithelium in the medulla (Payne 1985) and this proliferation contributes to the intensification of the production of Hassall's corpuscles and of subsequent changes which we regard as a manifestation of local cellular immunity. No explanation can be offered for the increase of myoid elements.

The pulpitis observed in the skin was a frequent finding in our experiments with isolate K. Payne (1985) in his study on MD has mentioned the occurrence of occasional lymphoid infiltrates in feather pulp without specifying their character. In our view, the pulpitis of the skin in strain $\mathrm{K}$-infected chickens is the result of viraemia and part of $\mathrm{MD}$-specific changes.

The pathogenesis of spheroids observed in the peripheral nerves is difficult to interpret; whether it is the case of primary or secondary degeneration cannot be decided without knowing the status of the respective ganglion cells. Nevertheless, some writers have described degenerative changes of heavily infiltrated nerves in MD as Waller's type of degeneration (Lampert et al. 1977). From some other studies, however, it appears that primary demyelination is caused by an immunopathological process and evidence has been obtained to indicate that

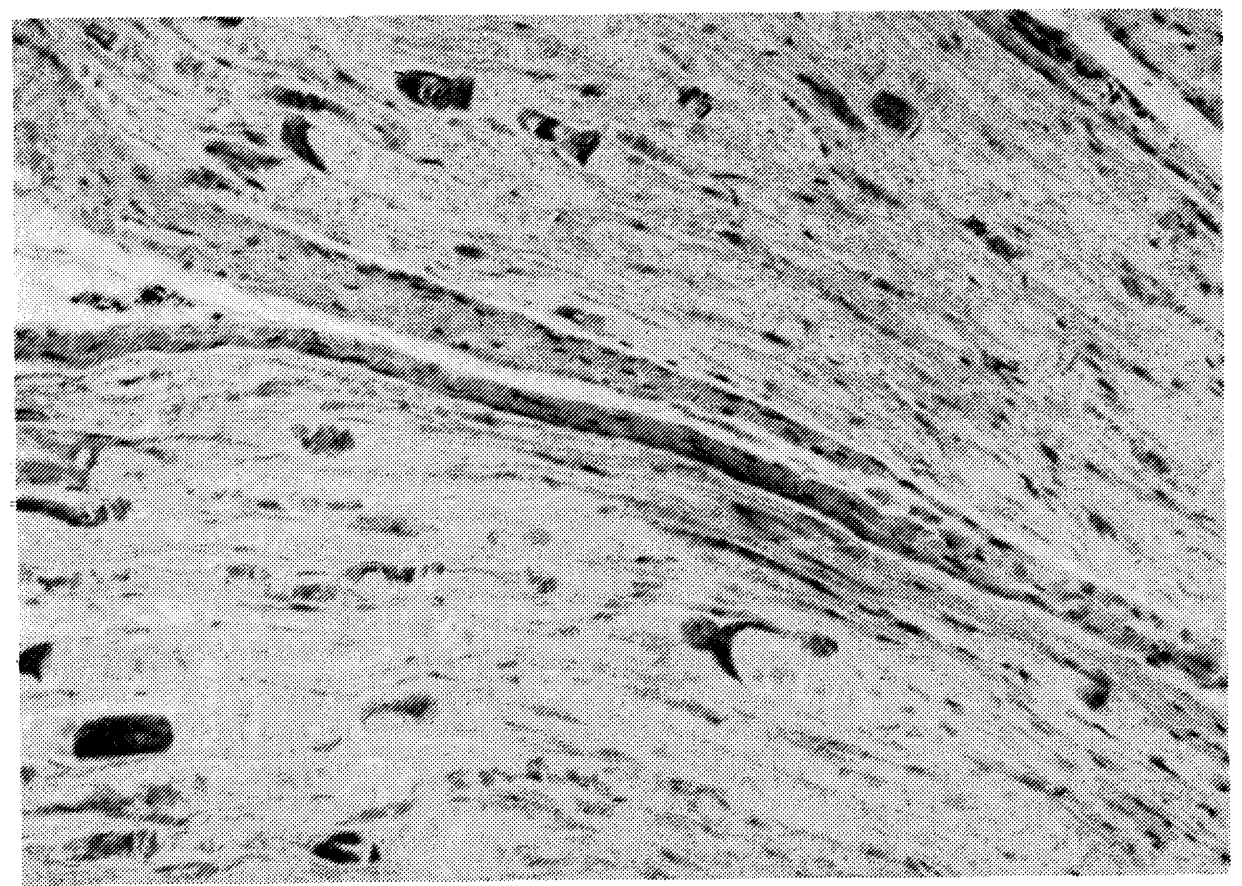

Fig. 4. Multiple spheroids in neuraxons of the $n$. ischiadicus. HE $\times 640$. 


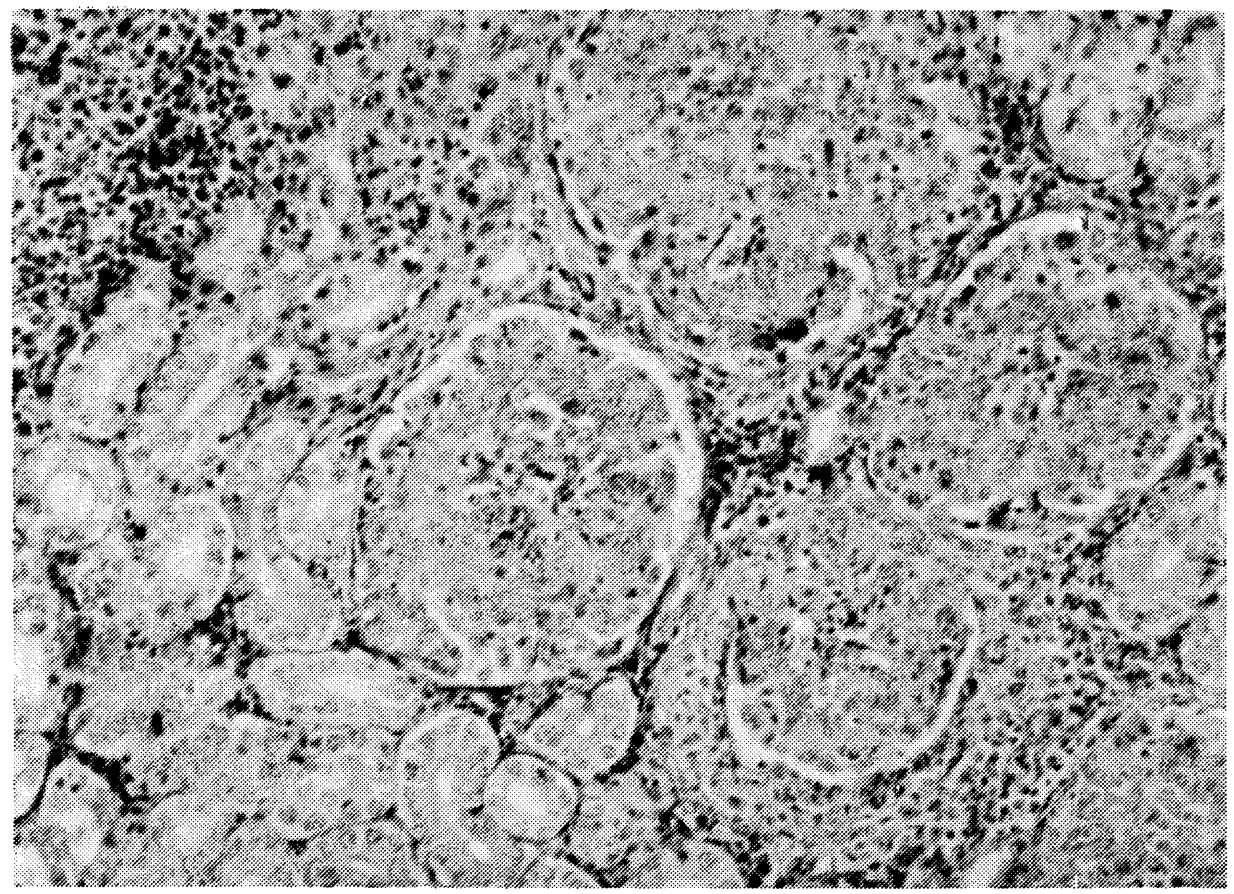

Fig. 5. Proliferation of mesangium, swelling of capillary endothelia and thickening of basement membranes in the renal glomeruli. $\mathrm{HE} \times 640$.

idiopathic polyneuritis is a spontaneous autoimmune disease of poultry (Pepose et al. 1981). In our view, a similar process cannot be excluded in our experiments with MDV strain RB-1B.

The cause of renal changes cannot be detected with the methods used in our study. An autoimmune character of similar changes has been demonstrated (Ley and Yamamoto 1979, Winter and Majid 1984). The description by Pradham et al. (1988) of immune complex-mediated glomerulopathy in MD 10 weeks after infection with $\mathrm{MDV}$ is morphologically identical with our findings.

Comparison of the morphological observations made in our experimental studies on the pathogenesis of MD with the corresponding results reported by other writers allows us to conclude that the changes in the BF and thymus are a manifestation of local cellular defence of the body and are not specific of MD. The changes in the nerves and kidney suggest their autoimmune character. The identification of the pathomorphological changes observed in the organs contributes to a better understanding of the complex pathogenesis of MD.

\section{Nespecifické morfologické změny $\mathbf{v}$ orgánech kuřat po experimentální infekci viry Markovy nemoci}

Práce pojednává o dosud nepozorovaných patologických změnách $\mathrm{v}$ orgánech experimentálních kư̌at genotypů Hybro. Hisex bílý, inbredních linií $\mathrm{F}_{1} \mathrm{CB} \times \mathrm{IA}$ a Brown Leghorn po infekci onkogenními kmeny (GA, terénní izoláty VUB-83, 
$\mathrm{RB}$-1B) a neonkogenními kmeny (terénní izoláty $\mathrm{M}$ a $\mathrm{K}$ ) $\mathrm{MDV}$. Kuřata byla infikována 2 . den věku a patomorfologicky vyšetřována $\mathrm{v}$ týdenních intervalech do 5. týdne p. i. Kromě $M D$-specifických a cytologických morfologických změn v orgánech, byly pozorovány syncytiální útvary, granulomy, „Hassal's corpuscle-like" struktury, dystrofické změny FAE buněk a změny kortikomedulární membrány ve folikulech Fabriciovy burzy, hypertrofie a hyperplazie Hassalových tělísek a hyperplasie myoidních elementů $\mathrm{v}$ thymu, sféroidy $\mathrm{v}$ periferních nervech a glomerulopathie.

Pozorované změny $\mathrm{v}$ lymfatických orgánech jsou považovány za morfologický projev místní celulární obrany a změny $\mathrm{v}$ nervech a ledvinách za autoimunitní proces a tudíž nespecifické pro $M D$. Jejich popis přispívá $k$ objasnění složité patogeneze Markovy nemoci drůbeže.

\section{Неспецифические морфопогические изменения органов цыплят после экспериментальной инфекции вирүсами болезни Марека}

В работе дается изложение до сих пор не наблюдаемых патологических изменений органов экспериментальных цыплят генотипов Гибро, Гисекс белый, инбредных линий F1 CBX IA и Браун Легхорн после инфекции онкогенными штаммами (GA, изолятами VUB-83, RB-1B) и неонкогенными штаммами (полученными в полевых условиях изолятами М и K) MDV. Цыплят инфицировали в возрасте двое суток и патоморфологически исследовали с недельным интервалом до 5 недели после инфекции. Помимо MD-специфических и цитологических морфологических изменений органов наблюдали синцитиальные формирования, грануломы "Hassal's corpuscle-like" структуры, дистрофические измения клеток FAE и измения кортико-медуллярной мембраны в фолликулах фабрициевой сумки, гипертрофию и гиперплазию телец Гассаля и гиперплазию миоидных элементов тимүса, сфероиды в периферических нервах и гломерулопатию.

Наблюдаемые изменения лимфатических органов считали морфологическим проявлением местной целлюлярной защиты и изменения нервов и почек - автоиммунным процессом и, следовательно неспецифическими для болезни Марека. Их описание вносит вклад в выяснение сложного патогенезиса болезни Марека птицы.

\section{References}

BEDNÁR̆, B.: Zánět. In: Patologie, Avicenum, Praha 1982: 200-281

BENDA, V.: Nádorová onemocnění jako model pro studium rezistence u kura. Dr. Sc. thesis, ČSAV Praha, 1990, 112p.

CALNEK, B. W.: MAREK's disease - A Model for Herpes Virus Oncology. Crit. Rev. Microbiol., 12, 1986: 293-320

EIDSON, C. S.-SCHMITTLE, S. C.: Studies on acute Marek's disease. I. Characteristics of isolate GA in chickens. Avian Dis., 12, 1968: 467-476

HALOUZKA, R. - JURAJDA, V.: Morphological Expression of Immunosuppression in poultry. Acta vet. Brno, 60, 1:91:2:1-276

HALOUZKA, R.-JURAJDA, V.: Izolace a studium biologických vlastností neonkogenních kuřecích herpesvirů Markovy nemoci. Patomorfologické vyhodnocení imunosuprese. Acta vet. Brno, 1991 (in press)

JEURISSEN, S. H. M.-JANSE, M.-KOK, G. L.-DeBOER, G. F.: Distribution and Func- 
tion of Non-Lymphoid Cells Positive for Monoclonal Antibody CVI-ChNL-68.2 in Healthy Chickens and those Infected with Marek's disease virus. Vet. Immunol. and Immunopathol., 22, 1989: 123-135

JURAJDA, V. - HALOUZKA, R.: Pathogenicity of a field Marek's disease virus isolate (VUB-83) for chickens of three genetically different types. Acta vet. Brno, 58, 1989: 273-279

JURAJDA, V.-HALOUZKA, R.: Izolace a studium biologických vlastností kuřecích herpesvirů a jejich využití při ochraně kuřat před Markovou nemocí drůbeže. Project report, VŞV Brno, 1990, 91 p.

JURAJDA, V.-HALOUZKA, R.: Izolace a studium biologických vlastností neonkogenních kuřecích herpesvirů Markovy nemoci. 1. Charakterizace in vitro. Veter. Med. (Praha), 1991 (in press)

JURAJDA, V. - HALOUZKA, R. - PLACHÝ, J.: Výskyt Markovy nemoci u geneticky odlišných skupin kuřat. Veter. Med. (Praha), 34, 1989: 629-636

LAMPERT, P.-GARRETT, R.-POWELL, H.: Demyelination in allergic and Marek's disease virus induced neuritis: Comparative electron microscopic studies. Acta Neuropathol. (Berl.), 40, 1977: 103-110

LEY, D. H.-YAMAMOTO R.: Immune complex involvement in the pathogenesis of infectious bursal disease virus in chicks. Avian Dis., 23, 1979: 219-224

LUPETTI, M. - DOLFI, A. - MICHELUCCI, S.: The behavior of Bursal Lymphoid Follicle-Associated Cells after treatment with testosterone. The Anatomical Record, 205, 1983a: $177-183$

LUPETTI, M.-DOLFI, A.-GIANNESSI, F.-MICHELUCCI, S.: Ultrastructural aspects of the lymphoid follicle-associated cells of the cloacal bursa after treatment with silica or carrageenn. J. Anat., 136, 1983b: $851-862$

NAUKKARINEN, A.-SORVARI, T. E.: Morphological and Histochemical Characterization of the Medullary Cells in the Follicles of the Chicken. Acta path. microbiol. immunol. Scand. Sect. C., 90, 1982: 193-199

PAYNE, L. N.: Pathology. In: Marek's disease. Martinus Nijhoff Publ., Boston, ed. L. N. Payne, 1985: 43-76

PAYNE, L. N.-BIGGS, P. M.: Studies on Marek's disease. II. Pathogenesis. J. Natl. Cancer Inst., 39, 1967: $281-302$

PEPOSE, J. S. - STEVENS, J. G.-COOK, M. L.-LAMPERT, P. W.: Marek's disease as a model for the Landry-Guillain-Barré syndrome. Am. J. Pathol., 103, 1981: 309-320

PRADHAN, H. K.-MOHANTY, G. C.-LEE, Y. W.-KAUL, L.-KATARIA, J. M.: Immune complex mediated glomerulopathy in Marek's disease. Vet. Immunol. Immunopathol., 19, 1988: 165-171

SYRJANEN, K. J.: The Lymph Nodes. Reactions to Experimental and Human Tumors. Experiment. Pathol., Suppl. 8, 1982

TOIVANEN, P.-NAUKKARINEN, A.-VAINIO, O.: What is the Function of Bursa of Fabricius? In: Avian Immunology, Basis and Practice, CRC Press, Boca Raton, ed. A. Toivanen and $\mathrm{P}$. Toivanen, 1, 1987: 79-99

WINTER, H.-MAJID, N. H.: Glomerulonephritis - an emerging disease. Vet. Bull., 54, 1984: $327-335$ 